\title{
Front Matter: Volume 7112
}

, "Front Matter: Volume 7112," Proc. SPIE 7112, Unmanned/Unattended Sensors and Sensor Networks V, 711201 (6 November 2008); doi: 10.1117/12.816766

SPIE. Event: SPIE Security + Defence, 2008, Cardiff, Wales, United Kingdom 


\section{PROCEEDINGS OF SPIE}

\section{Unmanned/Unattended Sensors and Sensor Networks $V$}

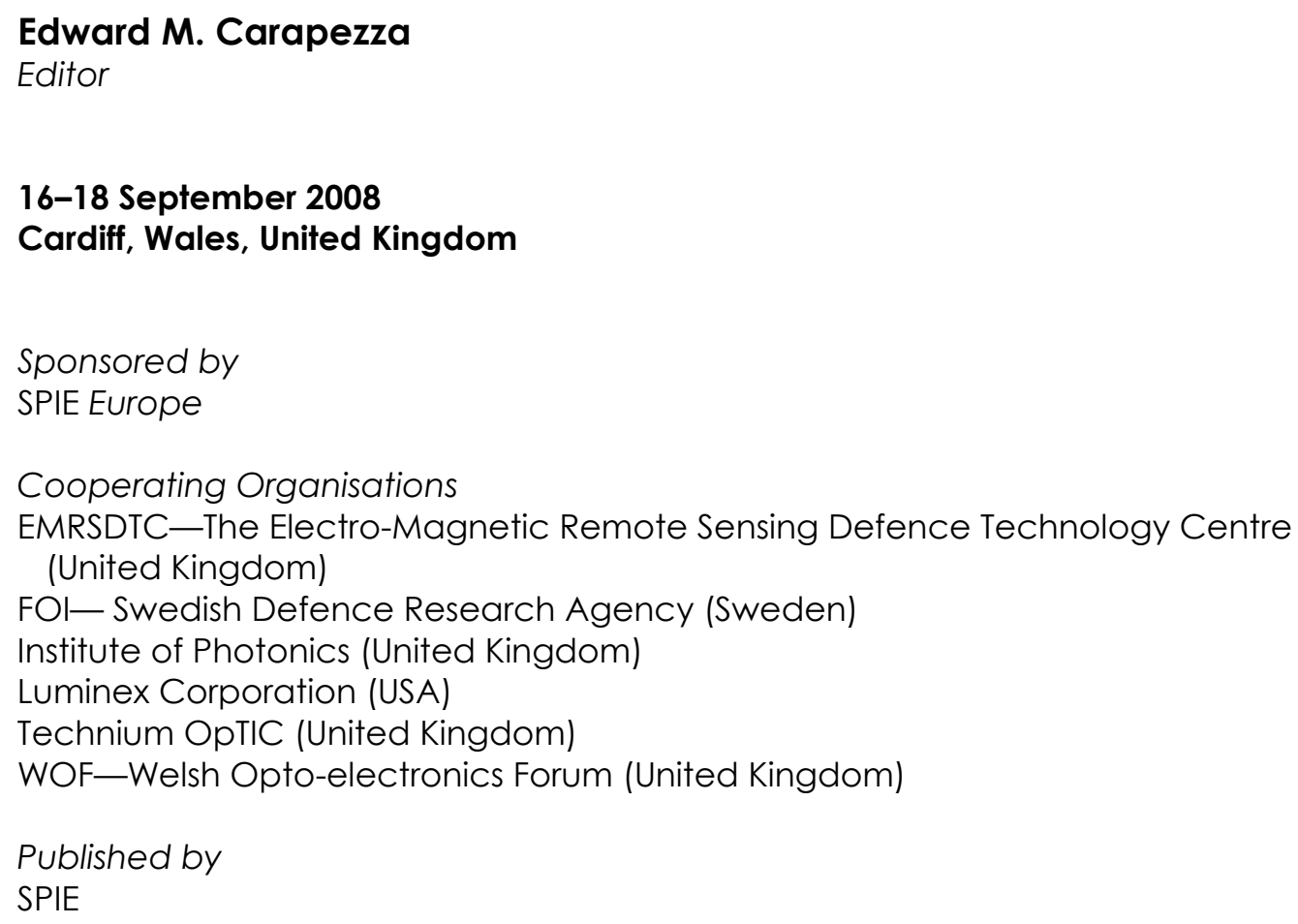


The papers included in this volume were part of the technical conference cited on the cover and title page. Papers were selected and subject to review by the editors and conference program committee. Some conference presentations may not be available for publication. The papers published in these proceedings reflect the work and thoughts of the authors and are published herein as submitted. The publisher is not responsible for the validity of the information or for any outcomes resulting from reliance thereon.

Please use the following format to cite material from this book:

Author(s), "Title of Paper," in Unmanned/Unattended Sensors and Sensor Networks V, edited by Edward M. Carapezza, Proceedings of SPIE Vol. 7112 (SPIE, Bellingham, WA, 2008) Article CID Number.

ISSN 0277-786X

ISBN 9780819473448

Published by

SPIE

P.O. Box 10, Bellingham, Washington 98227-0010 USA

Telephone +1 3606763290 (Pacific Time) · Fax +1 3606471445

SPIE.org

Copyright (C 2008, Society of Photo-Optical Instrumentation Engineers

Copying of material in this book for internal or personal use, or for the internal or personal use of specific clients, beyond the fair use provisions granted by the U.S. Copyright Law is authorized by SPIE subject to payment of copying fees. The Transactional Reporting Service base fee for this volume is $\$ 18.00$ per article (or portion thereof), which should be paid directly to the Copyright Clearance Center (CCC), 222 Rosewood Drive, Danvers, MA 01923. Payment may also be made electronically through CCC Online at copyright.com. Other copying for republication, resale, advertising or promotion, or any form of systematic or multiple reproduction of any material in this book is prohibited except with permission in writing from the publisher. The CCC fee code is $0277-786 \mathrm{X} / 08 / \$ 18.00$.

Printed in the United States of America.

Publication of record for individual papers is online in the SPIE Digital Library.

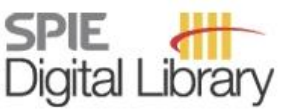

SPIEDigitallibrary.org

Paper Numbering: Proceedings of SPIE follow an e-First publication model, with papers published first online and then in print and on CD-ROM. Papers are published as they are submitted and meet publication criteria. A unique, consistent, permanent citation identifier (CID) number is assigned to each article at the time of the first publication. Utilization of CIDs allows articles to be fully citable as soon they are published online, and connects the same identifier to all online, print, and electronic versions of the publication. SPIE uses a six-digit CID article numbering system in which:

- The first four digits correspond to the SPIE volume number.

- The last two digits indicate publication order within the volume using a Base 36 numbering system employing both numerals and letters. These two-number sets start with 00, 01, 02, 03, 04, 05, $06,07,08,09,0 A, 0 B \ldots 0 Z$, followed by $10-12,20-2 Z$, etc.

The CID number appears on each page of the manuscript. The complete citation is used on the first page, and an abbreviated version on subsequent pages. Numbers in the index correspond to the last two digits of the six-digit CID number. 


\section{Contents}

vii Conference Committee
xi Introduction

\section{SENSOR NETWORKS}

711203 A system architecture for filtering and disseminating data in sensors networks [71 12-02] Y. Alayev, A. Bar Noy, CUNY (United States); F. Chen, The Pennsylvania State Univ. (United States); I. Fermin, Sytems Engineering Associates (United Kingdom); T. Pham, Army Research Lab. (United States); G. Pearson, Defence Science and Technology Lab. (United Kingdom); T. F. La Porta, CUNY (United States)

711204 Using classification to improve wireless sensor network management with the continuous transferable belief model [7112-03]

M. Roberts, D. Marshall, Cardiff Univ. (United Kingdom)

711205 A knapsack approach to sensor-mission assignment with uncertain demands [71 12-04]

D. Pizzocaro, Cardiff Univ. (United Kingdom); M. P. Johnson, CUNY (United States);

H. Rowaihy, The Pennsylvania State Univ. (United States); S. Chalmers, Univ. of Aberdeen (United Kingdom); A. Preece, Cardiff Univ. (United Kingdom); A. Bar-Noy, CUNY (United States); T. La Porta, The Pennsylvania State Univ. (United States)

711206 TActical Sensor network TEst bed (TASTE) [71 12-05]

Ir. Ph. van Dorp, H. H. P. Th. Bekman, Ing. R. D. J. Sandbrink, TNO Defence, Security and Safety (Netherlands)

\section{ADVANCED FREE-SPACE OPTICAL COMMUNICATIONS TECHNIQUES AND APPLICATIONS}

711207 UV solar-blind FSO sub-sea video communications: link budget study [7112-07]

S. Arnon, D. Kedar, Ben-Gurion Univ. of the Negev (Israel)

711208 A DC balancing algorithm for complex binary phase holograms [71 12-08]

P. Vachiramon, G. E. Faulkner, D. C. O'Brien, Univ. of Oxford (United Kingdom)

711209 FSO tracking and auto-alignment transceiver system [71 12-09]

G. A. Cap, H. H. Refai, J. J. Sluss, Jr., Univ. of Oklahoma (United States)

7112 OB Compact active high-resolution imaging system [7112-11]

I. Buske, W. Riede, Institute of Technical Physics (Germany)

ACTIVE AND PASSIVE IMAGERS, IMAGE SENSING, AND PROCESSING

7112 OF Building aerial mosaics for visual MTI [7112-17]

E. Turkbeyler, C. Harris, R. Evans, Roke Manor Research Ltd. (United Kingdom) 
$7112 \mathrm{OH} \quad$ Estimating dynamics of heavily fluctuating radar responses: a land clutter application and experimental results [71 12-19]

M. Väilä, J. Jylhä, H. Perälä, A. Visa, Tampere Univ. of Technology (Finland)

\section{SECURITY AND PERIMETER DETECTION}

7112 Ol Security applications of a remote electric-field sensor technology [7112-20]

R. J. Prance, C. J. Harland, H. Prance, Univ. of Sussex (United Kingdom)

$71120 \mathrm{~J}$ Aerial surveillance vehicles augment security at shipping ports [7112-21]

R. C. Huck, M. K. Al Akkoumi, S. Cheng, J. J. Sluss, Jr., T. L. Landers, Univ. of Oklahoma (United States)

7112 OK Updates to SCORPION persistent surveillance system with universal gateway [7112-22] M. Coster, J. Chambers, M. Winters, A. Brunck, Northrop Grumman Systems Corp. (United States)

\section{UNATTENDED SENSOR TECHNOLOGIES}

$7112 \mathrm{OL} \quad$ Unattended ground sensors for monitoring national borders [7112-23]

J. H. McQuiddy, McQ, Inc. (United States)

$71120 \mathrm{M}$ Compact integrated sensor processor: a common sensor processing core for the HYDRA unattended ground sensor system [7112-24]

G. Bourdon, SELEX Galileo (United Kingdom)

711200 Sustainable unattended sensors for security and environmental monitoring [7112-26]

E. M. Carapezza, T. M. Molter, Univ. of Connecticut, Avery Point (United States)

7112 OP Track-before-detect strategies for acoustic-seismic sensors [7112-27]

G. Prado, SenTech Inc. (United States)

$71120 Q \quad$ Optical cell monitoring system for underwater targets (Invited Paper) [71 12-28]

S. Moon, F. Manzur, Brigham and Women's Hospital, Harvard Medical School (United States); T. Manzur, Naval Undersea Warfare Ctr. (United States); U. Demirci, Brigham and Women's Hospital, Harvard Medical School (United States) and Harvard-MIT Health Sciences and Technology (United States)

7112 OR High-resolution chemical sensor for unattended underwater networks [7112-29]

L. Adornato, E. A. Kaltenbacher, SRI International (United States); R. H. Byrne, X. Liu,

R. Easley, Univ. of South Florida (United States)

7112 OT RF power amplifier design for high-efficiency applications [71 12-31]

P. Wright, C. Roff, T. Williams, J. Lees, J. Benedikt, P. J. Tasker, Cardiff Univ. (United Kingdom) 
$71120 \mathrm{U}$ Method of detection, classification, and identification of objects employing acoustic signal analysis [7112-32]

T. Orżanowski, H. Madura, T. Sosnowski, K. Chmielewski, Military Univ. of Technology (Poland)

$71120 \mathrm{~V}$ CCTV as an automated sensor for firearms detection: human-derived performance as a precursor to automatic recognition [7112-33]

I. T. Darker, A. G. Gale, A. Blechko, Loughborough Univ. (United Kingdom)

\section{UNMANNED SYSTEM TECHNOLOGY I}

$71120 \mathrm{~W}$ Improved cooperative planning for air vehicles searching for a ground object [7112-34] G. V. Moon, QinetiQ Ltd. (United Kingdom)

$71120 X$ Remote control of mobile robots through human eye gaze: the design and evaluation of an interface [7112-35]

H. O. Latif, N. Sherkat, A. Lotfi, Nottingham Trent Univ. (United Kingdom)

7112 OY Assessment of a visually guided autonomous exploration robot [7112-36]

C. Harris, R. Evans, E. Tidey, Roke Manor Research Ltd. (United Kingdom)

$71120 Z$ Fuzzy system reliability computation of the convoy of unmanned intelligent vehicles [7112-38]

H. Singh, A. M. Dixit, A. Mustapha, Wayne State Univ. (United States); G. R. Gerhart, U.S. Army Tank-Automotive Research, Development and Engineering Ctr. (United States)

\section{UNMANNED SYSTEM TECHNOLOGY II}

711211 Sensitivity analysis of an optimization-based trajectory planner for autonomous vehicles in urban environments [71 12-40]

J. Hardy, M. Campbell, I. Miller, B. Schimpf, Cornell Univ. (United States)

711212 Design and development of a family of explosive ordnance disposal (EOD) robots [7112-41]

K. Reichard, T. Simpson, C. Rogan, J. Merenich, S. Brennan, E. Crow, The Pennsylvania State Univ. (United States)

711213 On a new approach to reduction of data for ANFIS application to unmanned robotic vehicles [71 12-42]

H. Singh, A. Mustapha, S. Kamthan, A. M. Dixit, Wayne State Univ. (United States); D. Nam, Wilberforce Univ. (United States); G. Witus, Turing Associates, Inc. (United States);

G. R. Gerhart, U.S. Army Tank-Automotive Research, Development and Engineering Ctr. (United States)

711215 Optimizing sensor networks for autonomous unmanned ground vehicles [7112-44]

Y. Wang, D. P. Agrawal, Univ. of Cincinnati (United States)

Author Index 
Downloaded From: https://www.spiedigitallibrary.org/conference-proceedings-of-spie on 26 Apr 2023

Terms of Use: https://www.spiedigitallibrary.org/terms-of-use 


\title{
Conference Committee
}

\author{
Symposium Chair \\ David H. Titterton, Defence Science and Technology Laboratory \\ (United Kingdom) \\ Conference Chair
}

Edward M. Carapezza, University of Connecticut and DARPA (United States)

Program Committee

James S. Albus, National Institute of Standards and Technology (United States)

Jacques Bédard, Defence R\&D Canada, Valcartier (Canada)

Grant R. Gerhart, U.S. Army Tank-Automotive Research, Development and Engineering Center (United States)

Alan J. Gray, Defence Science and Technology Laboratory (United Kingdom)

Vincent A. Handerek, BAE Systems plc (United Kingdom)

Jeffrey R. Heberley, U.S. Army Armament Research, Development and Engineering Center (United States)

Todd M. Hintz, Space \& Naval Warfare Systems Command SPAWARSYSCEN (United States)

Myron E. Hohil, U.S. Army Research, Development and Engineering Command (United States)

Ivan Kadar, Interlink Systems Sciences, Inc. (United States)

Leslie C. Laycock, BAE Systems plc (United Kingdom)

Tariq Manzur, Naval Undersea Warfare Center (United States)

Tien Pham, Army Research Laboratory (United States)

Nino Srour, Army Research Laboratory (United States)

Huub A. J. M. van Hoof, TNO (Netherlands)

Graeme P. van Voorthuijsen, TNO-FEL (Netherlands)

\section{Session Chairs}

1 Keynote Session

Edward M. Carapezza, University of Connecticut and DARPA (United States)

Todd M. Hintz, Space \& Naval Warfare Systems Command SPAWARSYSCEN (United States) 
Edward M. Carapezza, University of Connecticut and DARPA (United States)

Todd M. Hintz, Space \& Naval Warfare Systems Command SPAWARSYSCEN (United States)

3 Advanced Free-Space Optical Communications Techniques and Applications

Leslie C. Laycock, BAE Systems plc (United Kingdom)

Vincent A. Handerek, BAE Systems plc (United Kingdom)

4

Keynote Session

Todd M. Hintz, Space \& Naval Warfare Systems Command SPAWARSYSCEN (United States)

Edward M. Carapezza, University of Connecticut and DARPA (United States)

5 Active and Passive Imagers, Image Sensing, and Processing

Tariq Manzur, Naval Undersea Warfare Center (United States)

Edward M. Carapezza, University of Connecticut and DARPA (United States)

6 Security and Perimeter Detection

Todd M. Hintz, Space \& Naval Warfare Systems Command SPAWARSYSCEN (United States)

Alan J. Gray, Defence Science and Technology Laboratory (United Kingdom)

7 Unattended Sensor Technologies

Edward M. Carapezza, University of Connecticut and DARPA (United States)

Todd M. Hintz, Space \& Naval Warfare Systems Command SPAWARSYSCEN (United States)

Tariq Manzur, Naval Undersea Warfare Center (United States)

Alan J. Gray, Defence Science and Technology Laboratory (United Kingdom)

Graeme P. van Voorthuijsen, TNO-FEL (Netherlands)

8 Sniper and Mortar Fire

Tariq Manzur, Naval Undersea Warfare Center (United States)

9 Unmanned System Technology I

Grant R. Gerhart, U.S. Army Tank-Automotive Research, Development and Engineering Center (United States)

Todd M. Hintz, Space \& Naval Warfare Systems Command SPAWARSYSCEN (United States) 
10 Unmanned System Technology II

Grant R. Gerhart, U.S. Army Tank-Automotive Research, Development and Engineering Center (United States)

Todd M. Hintz, Space \& Naval Warfare Systems Command SPAWARSYSCEN (United States) 
Downloaded From: https://www.spiedigitallibrary.org/conference-proceedings-of-spie on 26 Apr 2023

Terms of Use: https://www.spiedigitallibrary.org/terms-of-use 


\section{Introduction}

The interest in unmanned and unattended sensor and sensor networks has continued to increase over the past several years. Related systems are being developed in support of military, homeland security, intelligence, law enforcement, physical security, and environmental monitoring applications around the world. Government agencies around the world are making significant investments to develop improved unattended and unmanned sensor systems and sensor networks. This SPIE conference series is devoted to papers on recent technological advancements in systems, technologies, and applications in this challenging area.

The conference included three keynote/invited presentations and 38 technical paper presentations organized into 10 sessions covering recent advances in sensor networks; advanced free-space optical communications, active and passive imagers, image sensing, and processing; security and perimeter detection; unattended sensor technologies; sniper and mortar fire; and unmanned system technology.

The following three keynote/invited talks were given and we sincerely thank all of these speakers for very stimulating and relevant presentations:

1. "Super hard problems in realizing MANETs," by Dr. John A. Parmentola (Office of the Secretary of the Army)

2. "Realistic acquisition and 3D display of human characters," by Dr. Paul Debevec (University of Southern California)

3. "Science and technology roadmap for electro-optic and electronic warfare," by Dr. Robert Winston (Naval Air Systems Command), presented by Dr. Tariq Mansur (Naval Undersea Warfare Center).

Thanks to those who prepared and presented the technical papers and for their contributions to a very successful meeting. The success of this conference is attributed to the participation of the commercial, university, and government research-and-development communities as well as the organizing efforts of the diverse and talented program committee.

Thanks to our program committee members for their dedication, time, and assistance in conference planning and organizing and especially to those members who were able to participate as session chairs including: Grant R. Gerhart (U.S. Army Tank Automotive Research Development and Engineering Center), Vincent A. Handerek (BAE Systems plc), Todd M. Hintz (Space and Naval 
Warfare Systems Command), Leslie C. Laycock (BAE Systems plc), and Taria Mansur (Naval Undersea Warfare Center).

Finally, an extra special thanks to all of the conference attendees this year for your interest and enthusiasm. The conference was well attended with a lot of interest in all the sessions. We hope the interest in this technology continues to grow, and that this conference will expand with even greater technical content and significance in future years.

Edward M. Carapezza 